УДК 632.95.024:[631.87:636]:631.147

(C) 2014

Макаренко Н. А., доктор сільськогосподарських наук,

Бондарь В. І., кандидат сільськогосподарських наук,

Борщ Г. М., кандидат технічних наук,

Сальнікова А. В., аспірант

(науковий керівник - доктор сільськогосподарських наук Н. А. Макаренко)

Національний університет біоресурсів та природокористування України

\title{
ЕКОТОКСИКОЛОГІЧНА ОЦІНКА БІОДОБРИВ (ПРОДУКТІВ ФЕРМЕНТАЦІЇ БІОГАЗОВОЇ УСТАНОВКИ) НА ПРЕДМЕТ ЇХ ВІДПОВІДНОСТІ ВИМОГАМ ОРГАНІЧНОГО ВИРОБНИЦТВА
}

\section{Рецензент - доктор сільськогосподарських наук, професор В. М. Чайка}

\begin{abstract}
Проведено екотоксикологічну оиінку безпечності біодобрива - продукту переробки гною у біогазовіи установиі - за впливом на мікро- $i$ мезофауну трунту та сільськогосподарські рослини. На основі отриманих результатів було обтрунтовано екологобезпечні норми застосування біодобрива в органічному виробництвв продукиії рослинництвв. Встановлено, щзо застосування досліджуваного біодобрива позитивно впливає на урожайність сільськогосподарських культур, а за умов дотримання екологобезпечних норм внесення відсутній негативний вплив на агроекосистему.
\end{abstract}

Ключові слова: екотоксикологічна оцінка, екологічна безпечність, органічне виробництво, біодобриво, екологічне тестування.

Постановка проблеми. Згідно з законодавством України, в органічних господарствах заборонено використання хімічно синтезованих речовин для удобрення сільськогосподарських культур. У класичному розумінні таке сільськогосподарське виробництво передбачає використання замкнених циклів, зокрема таких, які об'єднують сектори рослинництва і тваринництва $[3,16]$. Прикладом такої практики може бути впровадження біогазових установок, що дають змогу ефективно використовувати відходи тваринництва та отримувати біогаз і біодобрива. Останні можна з успіхом використовувати у галузі рослинництва, проте, як і всі інші добрива природного походження, вони мають пройти екологічне оцінювання для попередження можливих негативних впливів на стан агроекосистеми та якість продукції.

Аналіз основних досліджень і публікацій, у яких започатковано розв'язання проблеми. У країнах ЄС застосування добрив в органічному виробництві регламентується Постановами Ради (СЕС) №2092/91 та (ЄС) №834/2007, в Україні - Законом України «Про виробництво та обіг органічної сільськогосподарської продукції та сировини» $[3,10,11,15,17]$. Під час оцінювання біодобрив найважливішими його показниками $€$ наявність небезпечних (токсикологічно значимих) домішок і метаболітів, а також вплив на біологічні об'єкти різних рівнів організації живої речовини $[1,5,6,9]$. Екотоксикологічні дослідження передбачають широке використання біотестів для встановлення екологічно безпечної норми внесення нових видів добрив $[2,4,7$, 8, 12-14]. Дослідження проводилися 3 використанням вищезазначених міжнародних вимог, методів і методичних підходів.

Мета дослідження полягала у проведенні екотоксикологічної оцінки біодобрива, отриманого шляхом переробки відходів тваринництва за допомогою біогазової установки та встановлення його придатності для використання в органічному виробництві продукції рослинництва.

Завдання досліджень - провести екотоксикологічну оцінку безпечності біодобрива за впливом на сільськогосподарські рослини, мікро- і мезофауну грунту; обгрунтування екологобезпечних норм його застосування в органічному виробництві продукції рослинництва.

Матеріали і методи досліджень. Досліджувалося біодобриво (ББУ), отримане шляхом ферментації гною від великої рогатої худоби. Біогазова установка працювала у мезофільному режимі роботи $\left(35^{\circ} \mathrm{C}\right)$, об'єм реактора $-3,5 \mathrm{~m}^{3}$, час повного циклу бродіння - 40 днів (період самозапуску - 15 днів, період виділення газу 25 днів). Біогазова установка була спроектована i встановлена у ВП НУБіП України «Агрономічна дослідна станція». У результаті роботи зазначеної біогазової установки було отримано ББУ наступного складу: загальний азот $-3,7 \pm 0,30 \%$; амонійний азот $-3,5 \pm 0,35 \%$; загальний фосфор

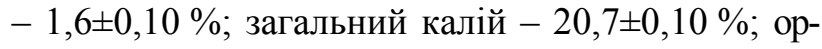
ганічна речовина $-12,5 \pm 0,80 \%$; волога $-99,2 \pm 0,30 \%$; сухий залишок $-0,8 \pm 0,30 \%$; $\mathrm{pH}-9,0 \pm 0,30$ ум. од. 


\section{СІЛЬСЬКЕ ГОСПОДАРСТВО. РОСЛИННИЦТВО}

Із метою вивчення біологічної ефективності ББУ було проведено польові дослідження кукурудзи (гібрид Дельфін), буряку цукрового (гібрид Настя), вівса (сорт Парламентський). ББУ вносили шляхом прикореневого підживлення кукурудзи і буряка цукрового, а також обприскуванням по вегетації вівса за наступною схемою:

1 - контроль (без добрив);

2 - норма внесення ББУ 10 т/га (кукурудза, буряк), 40 кг/га (овес);

3 - норма внесення ББУ 20 т/га (кукурудза, буряк), 80 кг/га (овес);

4 - норма внесення ББУ 30 т/га (кукурудза, буряк), 120 кг/га (овес).

Грунт - чорнозем типовий середньосуглинковий. Проби грунту відбиралися згідно з ДСТУ 4287:2004. Якість грунту. Догляд за культурами здійснювали за загальноприйнятими для даної зони технологіями. Екотоксикологічні дослідження ББУ проводили 3 використанням різних тест-об'єктів, а саме: визначення фітотоксичності чорнозему типового середньосуглинкового за методом Гродзинського; визначення гальмівної дії ББУ на ріст вищих рослин за ДСТУ ISO 11269-1:2004; дослідження загальної чисельності грунтових (педотрофних) мікроорганізмів та мікроміцетів за методикою Д. Г. Звягінцева; визначення гострої токсичності ББУ на дощових черв'яків (тест-культура Eisenia fetida) із застосуванням штучного субстрату за ДСТУ ISO 11268-1:2003; дослідження нітрифікаційної здатності грунту за методом Кравкова; інгібіторної дії на мінералізацію грунту - за ДСТУ ISO 14238:2003.

Результати досліджень. Загальновідомо, що першим етапом досліджень нових видів добрив має бути встановлення їх ефективності за впливом на врожайність сільськогосподарських культур. Лише за позитивного результату проводиться подальше вивчення їх властивостей, у тому числі вивчаються екотоксикологічні характеристики. Результати вивчення впливу ББУ на урожайність сільськогосподарських культур засвідчили, що максимальний приріст урожаю спостерігався у разі застосування 40 кг/га для вівса та 10 т/га - для кукурудзи і буряку цукрового: урожайність вівса збільшилася на 45,6 \% відносно контролю і склала 4,6 т/га; буряку цукрового 24,3 \% і 51,6 т/га, кукурудзи - 48,6 \% і 15,8 т/га відповідно. За умов подальшого підвищення норм застосування ББУ спостерігалася тенденція до зниження врожайності сільськогосподарських культур. Це явище змусило провести більш детальне вивчення явища 3 використанням методів біотестування для встановлення безпечних норм застосування добрива.

\section{1. Вилив ББУ на проростання насіння редису (трунт - чорнозем типовий середньосуглинковий)}

\begin{tabular}{|c|c|c|c|c|}
\hline Культура & Варіант досліду & $\begin{array}{c}\text { Схожість насіння } \\
\text { редису, \% }\end{array}$ & $\begin{array}{c}\text { Відхилення } \\
\text { від контролю, \% }\end{array}$ & $\mathrm{HIP}_{0,5}$ \\
\hline \multirow{4}{*}{$\begin{array}{c}\text { Овес } \\
\text { (сорт } \\
\text { Парламентський) }\end{array}$} & Контроль & 79,8 & 0,0 & \multirow{4}{*}{2,7} \\
\hline & 40 кг/га & 82,3 & 3,2 & \\
\hline & 80 кг/га & 69,0 & $-13,5$ & \\
\hline & 120 кг/га & 66,9 & $-16,2$ & \\
\hline \multirow{4}{*}{$\begin{array}{l}\text { Цукровий буряк } \\
\text { (гібрид Настя) }\end{array}$} & Контроль & 89,4 & 0,0 & \multirow{4}{*}{4,0} \\
\hline & 10 т/га & 83,3 & $-6,8$ & \\
\hline & $20 \mathrm{~T} / г \mathrm{a}$ & 73,6 & $-17,6$ & \\
\hline & 30 т/га & 64,9 & $-27,3$ & \\
\hline \multirow{4}{*}{$\begin{array}{c}\text { Кукурудза } \\
\text { (гібрид Дельфін) }\end{array}$} & Контроль & 83,3 & 0,0 & \multirow{4}{*}{3,8} \\
\hline & $10 \mathrm{t} / г \mathrm{a}$ & 75,7 & $-9,2$ & \\
\hline & 20 т/га & 72,7 & $-12,7$ & \\
\hline & 30 т/га & 64,4 & $-22,8$ & \\
\hline
\end{tabular}




\section{СІЛЬСЬКЕ ГОСПОДАРСТВО. РОСЛИННИЦТВО}

Першим кроком була перевірка грунту на фітотоксичність. Для цього було відібрано зразки грунту в польових дослідах після застосування ББУ і проведено лабораторні дослідження 3 пророщування насіння редису (сорт Червоний із білим кінчиком, який вважається досить чутливим до несприятливих грунтових умов). Отримані результати підтвердили припущення щодо пригнічення росту і розвитку рослин із підвищенням норм внесення ББУ. За результатами вивчення фітотоксичності грунту було визначено, що безпечною нормою ББУ під час підживлення рослин по вегетації буде 40 кг/га, за прикореневого внесення - 10 т/га (табл. 1).

Ці результати було підтверджено даними дослідження гальмівної дії ББУ на ріст вищих рослин, проведеними у відповідності з ДСТУ ISO 11269-1:2004. Норми ББУ збільшували у геометричній прогресії, що дало змогу встанови- ти чіткі залежності: підвищення норми застосування супроводжувалося уповільненням росту стебла і коріння ячменю. Екологічно безпечною була норма ББУ 10 т/га (табл. 2).

Другий блок екотоксикологічних досліджень стосувався питань впливу ББУ на процеси, що протікають у грунті. Найбільш чутливими тесторганізмами вважаються мікроорганізми й окремі їх функціональні групи, в першу чергу ті, які беруть участь у перетворенні сполук азоту і вуглецю. Мікробіологічний аналіз чорнозему типового після внесення ББУ у польовому досліді, безсумнівно, свідчить про пригнічення мікробіологічної діяльності. Істотне зменшення загальної чисельності грунтових мікроорганізмів спостерігалося внаслідок прикореневого внесення ББУ під кукурудзу і буряк цукровий: 3 11,4-12,0 млн КУО/Г сухого грунту вона знизилася до рівня $1,4-4,2$ млн КУО/г сухого грунту (табл. 3 ).

\section{2. Вилив ББУ на ріст ячменю (Hordeum vulgare L.), сорт Tріумф}

\begin{tabular}{|c|c|c|c|c|}
\hline $\begin{array}{c}\text { Норма внесення } \\
\text { ББУ }\end{array}$ & $\begin{array}{c}\text { Довжина кореня, } \\
\text { мм }\end{array}$ & $\begin{array}{c}\text { Відхилення } \\
\text { від контролю, \% }\end{array}$ & $\begin{array}{c}\text { Довжина стебла, } \\
\text { мм }\end{array}$ & $\begin{array}{c}\text { Відхилення } \\
\text { від контролю, \% }\end{array}$ \\
\hline Без добрив & 44 & 0 & 118 & 0 \\
\hline $10 \mathrm{~T} /$ га & 66 & $+50,0$ & 158 & $+33,9$ \\
\hline $30 \mathrm{~T} /$ га & 62 & $+40,9$ & 146 & $+23,7$ \\
\hline $90 \mathrm{~T} /$ га & 36 & $-18,2$ & 138 & $+16,9$ \\
\hline $270 \mathrm{~T} /$ га & 34 & $-22,7$ & 123 & $+4,2$ \\
\hline $810 \mathrm{~T} /$ га & 30 & $-31,8$ & 105 & $-11,0$ \\
\hline $\mathrm{HIP}_{0,5}$ & 4,6 & \multicolumn{3}{c|}{15,9} \\
\hline
\end{tabular}

3. Вилив ББУ на загальну чисельність мікроорганізмів чорнозему типового середньосуглинкового (польовий дослід)

\begin{tabular}{|c|c|c|}
\hline \multirow{2}{*}{ Культура } & Варіант досліду & $\begin{array}{c}\text { Загальна чисельність грунтових } \\
\text { мікроорганізмів, } \\
\text { млн КУО/г сухого грунту }\end{array}$ \\
\hline \multirow{3}{*}{$\begin{array}{c}\text { Овес } \\
\text { (сорт Парламентський) }\end{array}$} & Контроль (без добрив) & 3,0 \\
\cline { 2 - 3 } & 40 кг/га & 2,4 \\
\cline { 2 - 3 } & 80 кг/га & 1,8 \\
\hline \multirow{3}{*}{$\begin{array}{c}\text { Цукровий буряк } \\
\text { (гібрид Настя) }\end{array}$} & Контроль (без добрив) & 12,0 \\
\cline { 2 - 3 } & 10 т/га & 2,3 \\
\cline { 2 - 3 } & 20 т/га & 4,2 \\
\hline \multirow{3}{*}{$\begin{array}{c}\text { Кукурудза } \\
\text { (гібрид Дельфін) }\end{array}$} & 30 т/га & 3,2 \\
\cline { 2 - 3 } & Контроль (без добрив) & 11,4 \\
\cline { 2 - 3 } & 10 т/га & 3,3 \\
\cline { 2 - 3 } & 20 т/га & 3,1 \\
\hline
\end{tabular}


СІЛЬСЬКЕ ГОСПОДАРСТВО. РОСЛИННИЦТВО

\section{4. Вплив ББУ на нітрифікаційну здатність чорнозему типового середньосуглинкового та інгібіторну дію на процеси мінералізації}

\begin{tabular}{|c|c|c|}
\hline Варіант досліду & $\begin{array}{c}\text { Нітрифікаційна здатність грунту, } \\
\text { мг/кг }\end{array}$ & $\begin{array}{c}\text { Інгібіторна дія на мінералізацію } \\
\text { (ID) }\end{array}$ \\
\hline Контроль (без добрив) & 130,8 & - \\
\hline 10 т/га & 153,5 & $-22,6$ \\
\hline 20 т/га & 130,4 & $+0,5$ \\
\hline 30 т/га & 125,4 & $+5,5$ \\
\hline 40 т/га & 122,4 & $+8,4$ \\
\hline
\end{tabular}

$\mathrm{HIP}_{0,5}=7,14$

5. Екотоксикологічна оцінка ББУ за реакцією трунтових черв'яків (Eisenia fetida)

\begin{tabular}{|c|c|c|c|c|}
\hline Варіант & $\begin{array}{c}\text { Відсоток } \\
\text { смертності, \% }\end{array}$ & $\begin{array}{c}\text { Зміна біомаси, } \\
\text { \% від початкової } \\
\text { маси }\end{array}$ & Рухливість & $\begin{array}{c}\text { Реакція на світлове } \\
\text { та механічне } \\
\text { подразнення }\end{array}$ \\
\hline Контроль (вода) & 0 & $+3,3$ & рухливі & позитивна \\
\hline $10 \mathrm{~T} / г$ га & 0 & $+3,8$ & рухливі & позитивна \\
\hline $20 \mathrm{\tau} /$ га & 0 & $+5,8$ & рухливі & позитивна \\
\hline $30 \mathrm{~T} /$ га & 0 & $+2,0$ & рухливі & позитивна \\
\hline $40 \mathrm{\tau} /$ га & 0 & $+3,0$ & рухливі & позитивна \\
\hline
\end{tabular}

Надзвичайно важливими показниками біологічної активності грунту є направленість процесів перетворення сполук азоту, в т. ч. нітрифікації, денітрифікації, амоніфікації тощо. Саме вони визначають рівень грунтової родючості, активність синтезу і мінералізації органічних речовин, що $є$ основою забезпечення рослин поживними елементами. Одним із основних показників біологічної активності грунту є його нітрифікаційна здатність.

Дослідження впливу ББУ на нітрифікаційну здатність грунту показали, що застосування 10 т/га призводить до іiі підвищення, проте за подальшого збільшення норми відбувається пригнічення активності мікроорганізмів, які забезпечують перетворення азоту до нітратної форми (табл. 4).

Водночас спостерігається підвищення інгібіторної дії ББУ на процеси мінералізації, про що свідчить коефіцієнт ID: під час збільшення норми ББУ з 20 до 40 т/га він збільшився на 0,5-8,4 одиниць (за норми 10 т/га спостерігалося стимулювання на рівні 22,6 одиниць).

Аналіз токсичного впливу на грунтову мезофауну за реакцією найбільш чутливих тесторганізмів - дощових черв'яків виду Eisenia fetida - не виявив токсичного впливу. Підвищен- ня норми внесення ББУ 310 до 40 т/га не призвело до збільшення (летальності) смертності, не спричинило зміни рухливості та реакції на світлове й механічне подразнення. Зміни біомаси черв'яків коливалися в межах $+3,3 \ldots+5,8 \%$; спостерігалася тенденція до збільшення за внесенням ББУ на рівні 10-20 т/га та зменшення за збільшенням норми до 30-40 т/га. Проте в цілому пригнічення ББУ дощових черв'яків не спостерігалося (табл. 5).

Середня летальна концентрація LC50 для Eisenia fetida в умовах голодного тесту, під час якої кількість загиблих особин досягає рівня $10 \%$, створюється за норми ББУ на рівні 540 т/га і вище.

\section{Висновки:}

1. Екотоксикологічна оцінка біодобрива, отриманого в результаті переробки відходів тваринництва за використання біогазової установки, дало змогу встановити його екологічно безпечні норми застосування під сільськогосподарські культури.

2. За реакцією фітотестів, екологічно безпечний рівень забезпечується, якщо норма внесення ББУ не перевищує 10 т/га за прикореневого способу внесення і 40 кг/га - шляхом обприскування рослин по вегетації. 


\section{СІЛЬСЬКЕ ГОСПОДАРСТВО. РОСЛИННИЦТВО}

3. За реакцією мікроорганізмів грунту, безпечний рівень впливу ББУ може бути забезпечений, якщо норма застосування добрива не перевищуватиме 10 т/га.

4. Встановлено, що ББУ не чинить негативного впливу на мезофауну грунту, що підтверджено результатами дослідження грунтових черв'яків

\section{БІБЛІОГРАФІЯ}

1. Агрохімікати. Встановлення допустимих концентрацій шкідливих речовин : ДСТУ 4944:2008. [Чинний від 2009.01.01]. - К. : Держспоживстандарт України, 2009. - 8 с. - (Національний стандарт України).

2. Гродзинский А. М. Аллелопатия в жизни растений и их сообществ / А. М. Гродзинський. - К. : Наукова думка, 1965. - $198 \mathrm{c}$.

3. Закон України від 03.09.2013 №425-VII «Про виробництво та обіг органічної сільськогосподарської продукції та сировини» [Електронний ресурс]. - Режим доступу : http://zakon 2.rada.gov.ua /laws/show/425-18.

4. Лісовал А. Н. Агрохімія: лабораторний практикум /А. Н. Лісовал, У. М. Давиденко, Б. М. Мойсеєнко. - К. : Вища школа, 1984. - 311 с.

5. Макаренко Н. А. Органічна сільськогосподарська продукція : основні вимоги до якості та умов виробництва : науково-методичні рекомендації / [Н. А. Макаренко, М. Д. Мельничук та ін.] ; за ред. д. с.-Г. н., проф. Н. А. Макаренко. К. : НУБіП України, 2013. - 96 с.

6. Макаренко Н. А. Органічне виробництво сільськогосподарської продукції: основні передумови впровадження в Україні / Н. А. Макаренко, B. I. Бондарь // Сборник научных трудов Sworld. Одеса, 2013. - Т. 50. - Вип. 4, (Серия «Сельское хазяйство»). - С. 23-27.

7. Методы почвенной микробиологии и биохимии : [под ред. Д. Г. Звягинцева]. - М. : МГУ, 1991. - $304 \mathrm{c}$.

8. Нетрусов А. И. Практикум по микробиологии / [А. И. Нетрусов, М. А. Егорова и др.] ; под ред. А. И. Нетрусова. - М. : Изд. центр «Академия», 2005. -608 с.

9. Патика В. П. Агроекологічна оцінка мінеральних добрив та пестицидів / [В. П. Патика, Н. А. Макаренко та ін.]. - К. : Основа, 2005. $300 \mathrm{c}$.

10. Постанова ЄС №834/2007 від 28 червня 2007 року «Стосовно органічного виробництва i маркування органічних продуктів» [Електронний ресурс]. - Режим доступу : humana.ua/ec виду Eisenia fetida: середня летальна концентрація LC50 створюється за норми ББУ на рівні 540 т/га і вище.

5. За умов дотримання рекомендованих норм застосування ББУ можна використовувати в органічному виробництві продукції рослинництва.

komisiya_834_2007.pdf.

11. Постанова ЄС № 889/2008 від 5 вересня 2008 року «Детальні правила щодо органічного виробництва і контролю для впровадження постанови 834/2007» [Електронний ресурс]. - Режим доступу : http://organicfood.com.ua/organiche sko ezaknodatelstvo-es/.

12. Якість грунту. Біологічні методи. Визначення мінералізації азоту і нітрифікації в грунтах та впливу хімічних речовин на ці процеси (ISO 14238:1997, IDT) : ДСТУ ISO 14238:2003. [Чинний від 2003.11.06]. - К. : Держспоживстандарт України, 2004. - С. 12. - (Національний стандарт України).

13. Якість грунту. Визначання дії забрудників на земляних черв яків (Eisenia fetida). Частина 1. Визначання гострої токсичності 3 використанням штучного субстрату грунту (ISO 112681:1993, IDT) : ДСТУ ISO 11268-1:2003. - [Чинний від 2004.01.07]. - К. : Держспоживстандарт України, 2004. - С. 12. - (Національний стандарт України).

14. Якість грунту. Визначання дії забрудників на флору грунту. Частина 1. Метод визначення гальмівної дії на ріст коренів (ISO 1269-1:1993, IDT) : ДСТУ ISO 11269-1:2004. - [Чинний від 2004.30.04]. К. : Держспоживстандарт України, 2005. - С. 10. (Національний стандарт України).

15. Electronic code of federal regulations. Regulations of the department of agriculture (continued). Part 205. National organic program [Електронний pecypc]. - Режим доступу : http://www.ecfr. gov/cgi-bin/text-idx?c $=$ ecfr\&sid $=3 f 34 f 4 c 22 f 9 a a 8 e 6$ d9864cc2683cea02\&tpl=/ecfrbrowse/Title $07 / 7 \mathrm{cfr} 20$ 5_main_02.tpl.

16. Francis Charles Organic Farming: The Ecological System : monograph / Charles Francis. South Segoe Road, Madison, 2009. - 365 p.

17. Japanese Agricultural Standard for Organic Plants (Notification №1605 of 2005) (the last revision March, 2012) [Електронний pecypc]. Режим доступу : http://www.maff.go.jp/e/jas/ specific/organic.html. 